\title{
Ontological Models for Simulation of Building Construction Processes
}

\author{
Eric Forcael, Ph.D. ${ }^{1}$, Milen Salgado, P.E. ${ }^{1}$, Francisco Ramis, Ph.D. ${ }^{1}$, Francisco Orozco, Ph.D. ${ }^{2}$, and Carlos \\ Rodríguez, Ph.D. ${ }^{3}$ \\ 1'Universidad del Bío-Bío, Chile, eforcael@ubiobio.cl,milsalga@alumnos.ubiobio.cl,framis@ubiobio.cl \\ ${ }^{2}$ Universidad Panamericana, Mexico, forozco@up.edu.mx \\ ${ }^{3}$ Escuela Superior Politécnica del Litoral, Ecuador, crodrigu@espol.edu.ec
}

\begin{abstract}
The construction industry has a series of own practices and methods; which specifically depends on either the nature of construction works or the actions of the actors involved in construction activities. This makes evident the need of having tools that facilitate the construction management of projects, one of them: the simulation of construction processes. Thus, this paper presents a conceptualization of constructive operations, as a startpoint for the development of a library of objects for the simulation of construction processes in buildings. To do it, fieldwork was conducted to gather information about processes and resources, which were then modeled by using Unified Modeling Language (UML). To validate the conceptualization made, some of the models created were simulated by using Discrete Event Simulation.

Keywords-- Ontological models, Simulation, Constructive processes, Residential buildings.
\end{abstract}

\section{INTRODUCTION}

The need for innovating in the construction industry is recognized, as well as increasing the efficiency in housing production and improving the quality of these $[1,2]$. In this context, simulation appears as an innovative alternative for the analysis and improvement of constructive processes.

Simulation is a tool with diverse applications, which aims to improve the quality of processes, by studying the behavior of operations, proposing improvements regarding the use of resources, bottlenecks, production rates, among others [3].

In the construction industry, simulation of processes has been effective, although its application has been limited [4, 5]. This is due to the complexity of simulation languages, which demand specific knowledge and skills, making it difficult to use for construction professionals. In this industry, intuition and experience are over the analysis [6]; planners are reluctant to base their decisions on results provided by simulation [3].

This shows two challenges: (a) a countries' concern to increase productivity in construction, by using 3D modeling techniques to design and operate projects; (b) the need for simulation tools for construction processes, reducing time and effort for creating simulation models in construction projects, by $3 \mathrm{D}$ visualizations comprehensible to decision-makers.

\section{RESEARCH OBJECTIVES}

The general objective of this research is to develop conceptual models to simulate building construction processes, which help improve the productivity of them. The specific objectives are to (1) gather information about construction processes; (2) identify and characterize the activities, resources and elements of such processes; (3) propose conceptual models for construction processes; and (4) validate the models proposed, by simulating some constructive processes.

\section{LITERATURE REVIEW}

\section{A. Process Simulation}

1) The origins of Simulation

The first contemporary advances in simulation are found in the 60's, after the growth of computers for general use [7]. In 1961, SIMULA, the first object-oriented programming language, was created [8]. Its influence was one of the greatest in the field of computer science [9], since a number of objectoriented programming languages were based on SIMULA concepts [10]. Later, during the 70's, there was a period of expansion, with advances in simulation languages [9]. In the 80's and 90's, faster and less expensive computers [11] made the graphics animation a key feature for simulation tools, simplifying the building of models [10], while animations improved the visualization of simulations results [9]. During this time, a Unified Modeling Language (UML) was created to standardize the modeling techniques to help users to model their systems, facing better the object orientation [12].

Today, simulation software has common characteristics: intuitive user interface [11], animation, and automatic results [10], generating statistical analyzes (confidence intervals for performance, warm-up periods, correlation analyses, etc.) [10]. Some of the most used software are: Arena, ExtendSim, Flexsim, Mathlab, Simio, Simul8, among others [10, 13].

\section{2) What is Simulation?}

Simulation refers to the representation of a real system or process, which seeks to imitate its behavior over time [11], through a conceptual and/or computational model [10]. It is used to study a system and experiment with it, making changes in the model, in order to infer its performance [14].

\section{3) Simulation Models}

Simulation models are classified in static or dynamic, deterministic or stochastic, and discrete or continuous [11]. Since the discrete nature of construction activities (they can be discretized, e.g. trucks entering and exiting a construction site, $\mathrm{m}^{3}$ of concrete poured per hour, etc.), the ontological models of this research were based on Discrete Event Simulation.

\section{B. Simulation of Discrete Events}

In general, Discrete Events Simulation is used when the state variables of a modeled system change instantaneously in

Digital Object Identifier (DOI):

http://dx.doi.org/10.18687/LACCEI2019.1.1.456

ISBN: 978-0-9993443-6-1 ISSN: 2414-6390

$17^{\text {th }}$ LACCEI International Multi-Conference for Engineering, Education, and Technology: "Industry, Innovation, And Infrastructure for Sustainable Cities and Communities", 24-26 July 2019, Jamaica. 
separate periods of time $[10,13]$. It is the set of mathematical relationships, which represents the behavior of a simulated system. It is analyzed by numerical methods, i.e. an artificial history of the system is generated from the information collected. The real performance measures are analyzed and estimated, depending on the assumptions of the model [10].

\section{Simulation of Processes in Construction}

The first simulation methodologies in construction began in the 70's with Halpin [15], which evolved to be applied in several projects in the construction industry [16]. It has been used in: tunnel construction $[17,18]$; operation of tower cranes [4]; earthmoving projects [19, 20]; high-rise buildings projects [21]; construction of pavements, and roads [5, 22, 23].

Other examples on simulation of construction processes are: a modeling methodology to study the productivity of construction operations [24]; application of discrete event simulation to the analysis of labor productivity by comparing different systems [25]; a computerized simulation model used to compare prefabricated slab construction methods, optimizing times and costs [26]; the use of discrete event simulation as a tool for planning, analysis and reengineering of construction projects [27]; and discrete event simulation used to simplify scheduling of building construction processes [28].

With the advance of new computer techniques, graphicbased editing has been used along with programming techniques to model building systems, such as BIM (Building Information Modeling) technologies, where 4D visualizations optimize the integration of specialties effectively, since their ability to transfer information between them [29].

Despite the fact that both approaches, Discrete Events Simulation and BIM, have had the intention of solving the problems related to the modeling of construction projects $[30,31,32,33]$, there is limited evidence about the existence of libraries with previously designed objects that address the variability of systems and that include parameters that adapt to the simulation of construction processes.

\section{Unified Modeling Language (UML)}

The Unified Modeling Language (UML) is a language adopted internationally [34] for the creation of diagrams that visualize, specify, construct and document information related to the development of computer programs [8]. It was created to unify the existing modeling techniques and try to standardize the notations and terms of object orientation [12].

\section{1) UML Diagrams}

UML diagrams are a set of graphic elements that generate simple models to provide diverse views of a system [8, 34]. These diagrams have predetermined rules in the combination of elements, as the creators of systems create models capturing their ideas in a conventional and standardized way [35]. Booch et al. [8] classify the UML diagrams into dynamic or static. On the one hand, structural diagrams are used when the system to be modeled contains static parts, and on the other, behavior diagrams are used when dynamic parts are in the system.
As part of the methodology to carry out, UML diagrams are used to create conceptual models to represent the different stages of a project, where activity diagrams show the flows between activities through several objects, considering both concurrence and bifurcations [8].

\section{2) Activity Diagram}

One of the UML diagrams is the activity diagram, used to represent the dynamic behavior of a system, showing a flow of activities and tasks [36]. Activity diagrams contain states of action that symbolize the performance of operations; transitions triggered by the completion of those operations; decisions, which present the alternative paths of a flow of control; division and union nodes used when concurrent tasks are required; and streams that allow representing those responsible for the activity, dividing them into groups [36]. Table I presents the symbolization of each of the basic elements that allow representing the sequence of activities and the conditions that store or trigger those activities.

TABLE I

BASIC ELEMENTS OF AN ACTIVITY DIAGRAM

\begin{tabular}{|c|c|c|}
\hline Notation & Element & Description \\
\hline & $\begin{array}{l}\text { Initial } \\
\text { state }\end{array}$ & $\begin{array}{l}\text { Represents the start of a process or } \\
\text { workflow. It is used by itself or by entering } \\
\text { an expression that mentions the beginning. }\end{array}$ \\
\hline & $\begin{array}{l}\text { Action } \\
\text { state }\end{array}$ & $\begin{array}{l}\text { Represents an internal action state, with at } \\
\text { least one transition that identifies the } \\
\text { completion of an action. The action states are } \\
\text { symbolized by a rectangle with rounded tips } \\
\text { that expresses an activity or an action. }\end{array}$ \\
\hline & Transition & $\begin{array}{l}\text { Shows the transition from one action state to } \\
\text { another, and occurs once that stage is } \\
\text { completed. The symbol of a transition is a } \\
\text { line accompanied by an arrow that shows the } \\
\text { directional flow of each activity or action. }\end{array}$ \\
\hline & Decision & $\begin{array}{l}\text { Is used when the flow does not have a } \\
\text { sequential behaviour, but has alternative } \\
\text { paths. Its rhombus shape accepts an entrance } \\
\text { transition, and up to three exit transitions. }\end{array}$ \\
\hline & Division & $\begin{array}{l}\text { Graphically represents concurrent or parallel } \\
\text { tasks. It is symbolized by means of a thick } \\
\text { horizontal or vertical line along with an entry } \\
\text { arrow and two or more exit arrows, which } \\
\text { denote the division of an individual activity } \\
\text { into two or more activities in parallel. }\end{array}$ \\
\hline & Union & $\begin{array}{l}\text { Marks the end of activity flows in parallel. It } \\
\text { contains two or more arrows, representing } \\
\text { the input of parallel or concurrent tasks, } \\
\text { followed by a horizontal or vertical thick } \\
\text { line, ending with an output arrow that shows } \\
\text { the combination of concurrent activities } \\
\text { reintroducing them in the sequential flow. }\end{array}$ \\
\hline Stream & Stream & $\begin{array}{l}\text { Action states can be organized in streams, } \\
\text { which are useful to divide the states of action } \\
\text { into groups, representing responsibilities of } \\
\text { each set of action states, where each stream } \\
\text { represents the responsible for the activities } \\
\text { that appear in it. The diagram is divided by } \\
\text { continuous vertical lines on both sides. }\end{array}$ \\
\hline & $\begin{array}{l}\text { Final } \\
\text { State }\end{array}$ & $\begin{array}{l}\text { The final state represents the completion of a } \\
\text { process or workflow. }\end{array}$ \\
\hline
\end{tabular}

$17^{\text {th }}$ LACCEI International Multi-Conference for Engineering, Education, and Technology: "Industry, Innovation, And Infrastructure for Sustainable Cities and Communities", 24-26 July 2019, Jamaica. 


\section{METHODOLOGY}

In the study, concepts related to processes were applied, which allowed observing and graphing items that are carried out in the construction site. In addition, Figure 1 shows the methodology used in the present study.

To build the construction process, first, different construction' professionals were interviewed. Secondly, data collection was conducted on site, which consisted of visiting construction projects, to know the development of construction activities. Information about procedures, scheduling, and technical specifications was obtained. Literature related to constructive processes was also consulted $[37,38]$.

Later, the most important items in the construction process were identified. The collected data was analyzed and then, conceptual models of the constructive processes were built, by using UML activity diagrams.

With the support of the FlexSim ${ }^{\mathrm{TM}}$ software, the validation of the proposed conceptual models was carried out, by simulating some of the constructive processes present in construction work.

FIGURE 1

METHODOLOGY OF THE STUDY

\begin{tabular}{|c|c|c|c|c|}
\hline Objectives & \multicolumn{3}{|c|}{ Activities } & \multirow{2}{*}{ 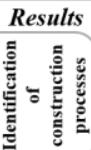 } \\
\hline $\begin{array}{l}\text { 1. Survey of } \\
\text { construction } \\
\text { processes }\end{array}$ & 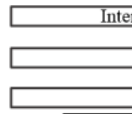 & $\begin{array}{c}\text { with construction } \\
\downarrow \\
\text { Field visits } \\
\frac{\downarrow}{\text { taining informati }} \\
\end{array}$ & lists & \\
\hline $\begin{array}{l}\text { 2. Identify and } \\
\text { characterize } \\
\text { activities and } \\
\text { resources }\end{array}$ & $\begin{array}{l} \\
\text { Characterization } \\
\text { of the } \\
\text { construction } \\
\text { process }\end{array}$ & $\begin{array}{l}\text { Characterization } \\
\text { of construction } \\
\text { techniques }\end{array}$ & $\begin{array}{c}\text { Classification of } \\
\text { construction } \\
\text { resources }\end{array}$ & 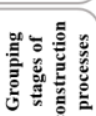 \\
\hline $\begin{array}{l}\text { 3. Construction } \\
\text { of the } \\
\text { conceptual }\end{array}$ & $\begin{array}{l}\text { Const } \\
\text { Constru } \\
\end{array}$ & 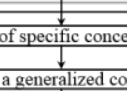 & I odels & 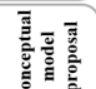 \\
\hline $\begin{array}{l}\text { 4. Construction } \\
\text { of the } \\
\text { computational } \\
\text { model }\end{array}$ & & $\begin{array}{l}n \text { of the FlexSim } \\
\text { nstruction proce }\end{array}$ & & 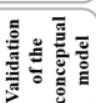 \\
\hline
\end{tabular}

\section{DEVELOPMENT OF ONTOLOGICAL MODELS}

In general, an ontology is an explicit specification of a conceptualization [39], which allows the presentation of concepts related to a certain scope and their respective relationships, with the aim of solving problems, improving communication, management, and dissemination of knowledge [40]. In this sense, the use of ontological models becomes a useful tool for describing construction processes, which can be represented through the use of discrete event simulation.

Given the importance of building construction in the construction industry and the cyclical characteristics in the execution of its processes, it was decided to develop conceptual models for this type of project. The following are some of the activities for the ontological models built:

\section{A. Preliminary works}

The preliminary works are those activities or "items" built at the beginning of the project, and before the structural works. Its construction begins with the move-in activities, perimeter fences, temporary facilities, and crane setup, which are developed in parallel as shown in Figure 2.

FIGURE 2

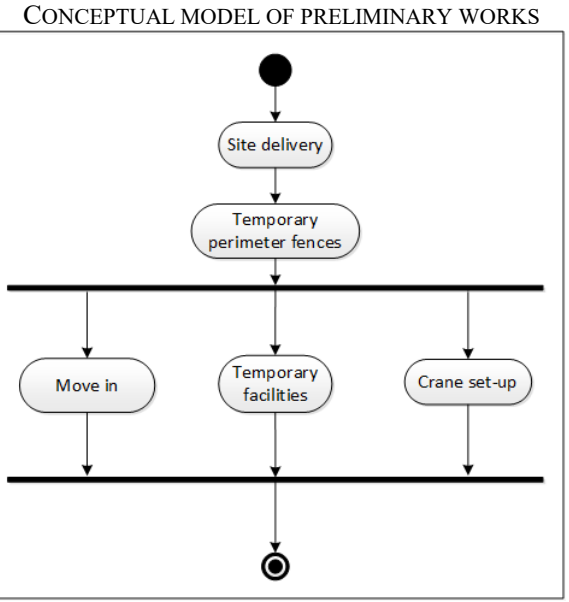

\section{B. Excavations and compaction of the land}

As shown in Figure 3, the tracers demarcate the area to be excavated. Then, the excavations are carried out mechanically by using a backhoe machine. After, the ground must be compacted to receive the foundations.

FIGURE 3

EXCAVATIONS AND SOIL COMPACTION

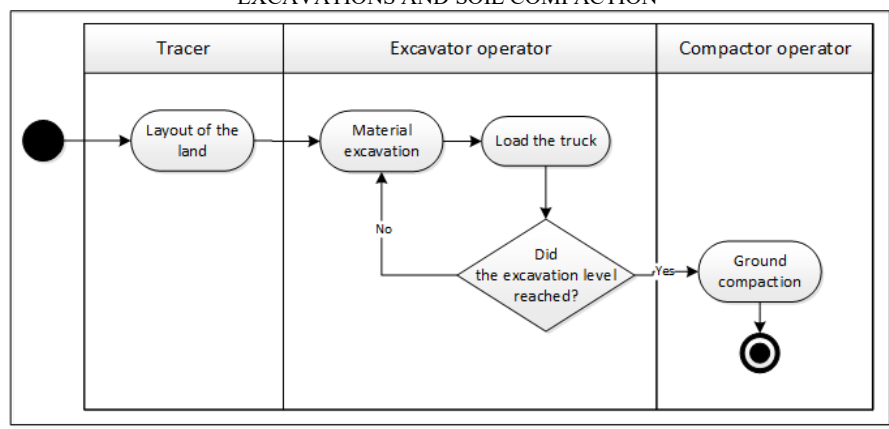

Involved resources: Backhoe machine, smooth vibrating roller and hopper truck.

\section{Structural work}

Structural work includes the structural items of a building. The activities of this stage are divided into lean concrete base, foundations, walls, slabs, and structures, which are subdivided into reinforced bars, formworks, and concrete.

\section{Lean concrete base}

It is a layer of poor concrete used to level the surface that will receive the reinforced bars and concrete. The aim is to achieve a flat and even surface after the excavation profiling.

This task starts with the trace of the base for the subsequent placement of the formwork by carpenters. At the arrival of the mixer truck, the concrete is spread by concretemen with wheelbarrows and shovels. As the concrete

$17^{\text {th }}$ LACCEI International Multi-Conference for Engineering, Education, and Technology: "Industry, Innovation, And Infrastructure for Sustainable Cities and Communities", 24-26 July 2019, Jamaica. 
is poured, the workers set and tamp the concrete until getting a smooth and even surface. Then, the formworks are removed and the concrete is cured. Figure 4 shows the conceptual model of construction process of the lean concrete base.

FIGURE 4

CONSTRUCTION PROCESS OF THE LEAN CONCRETE BASE

\begin{tabular}{|c|c|c|c|}
\hline Tracer & Carpenter & Non-skilled worker & Bricklayer \\
\hline
\end{tabular}

Involved resources: Lean concrete base formworks, mixer truck, wheelbarrows, shovels, roller, and trowel.

\section{E. Foundations}

Foundations are structures responsible for transmitting the loads and efforts of the building to the ground that supports the construction. The construction process of foundations begins with the trace of axes and thicknesses of the walls. Depending on the type of project, this reinforcement is moved manually or through the use of cranes. Then the steel bar workers install the reinforcement of foundations along with the wall starts as shown in Figure 5.

Next, the carpenters install the formworks so the concrete is poured. The concrete is sent from the mixer truck to the foundation in three ways; by using a stationary pump, a telescopic pump, or a crane and its bucket.
FIGURE 5

CONSTRUCTION PROCESS OF FOUNDATIONS' REINFORCEMENT

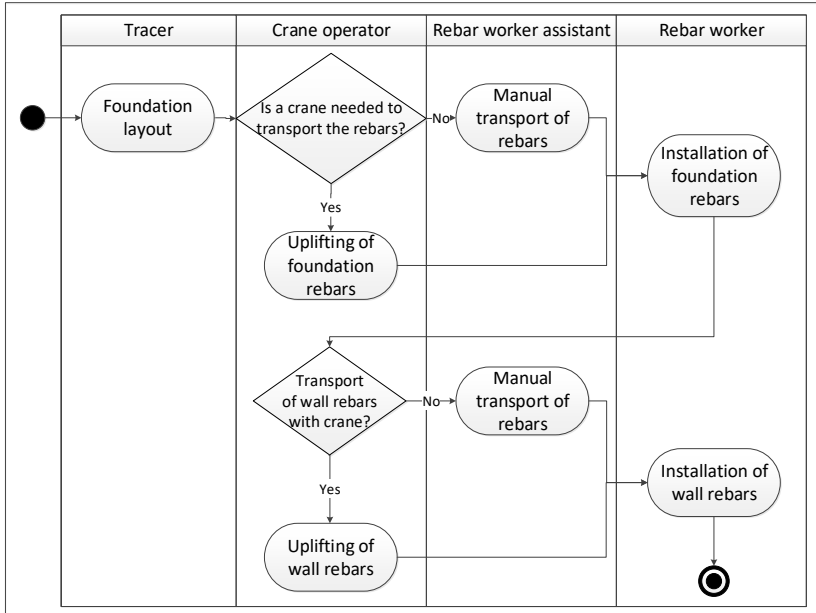

Later, vibration is done for compacting the concrete and eliminating the air from it. Finishing is got with a concrete power trowel. After pouring the concrete, the workers carry out the curing process, and then the carpenters remove the formworks. Finally, the workplace is cleaned up. The complete model related to this construction activity is shown in Figure 6.

Involved resources: Crane, wheelbarrow, stationary and telescopic pumps, hod, concrete vibrator, and frames.

Subsequently, Figure 7 shows the conceptual model that fully explains how the constructive process for foundations is conducted.

FIGURE 6

CONSTRUCTION PROCESS OF FORMWORKS AND CONCRETE OF FOUNDATIONS

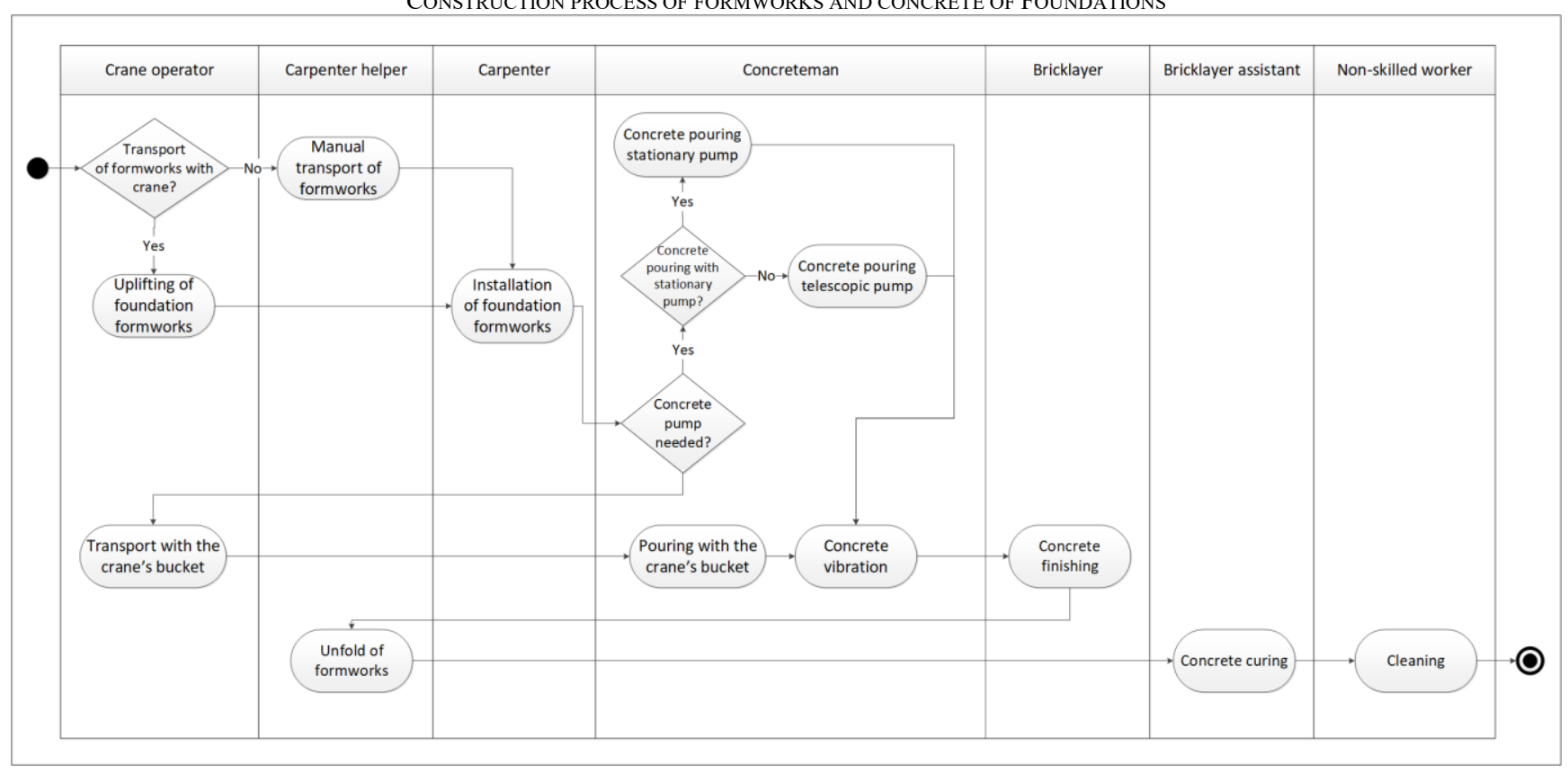

$17^{\text {th }}$ LACCEI International Multi-Conference for Engineering, Education, and Technology: "Industry, Innovation, And Infrastructure for Sustainable Cities and Communities", 24-26 July 2019, Jamaica. 
FIGURE 7

CONCEPTUAL MODEL OF THE CONSTRUCTION PROCESS OF FOUNDATIONS

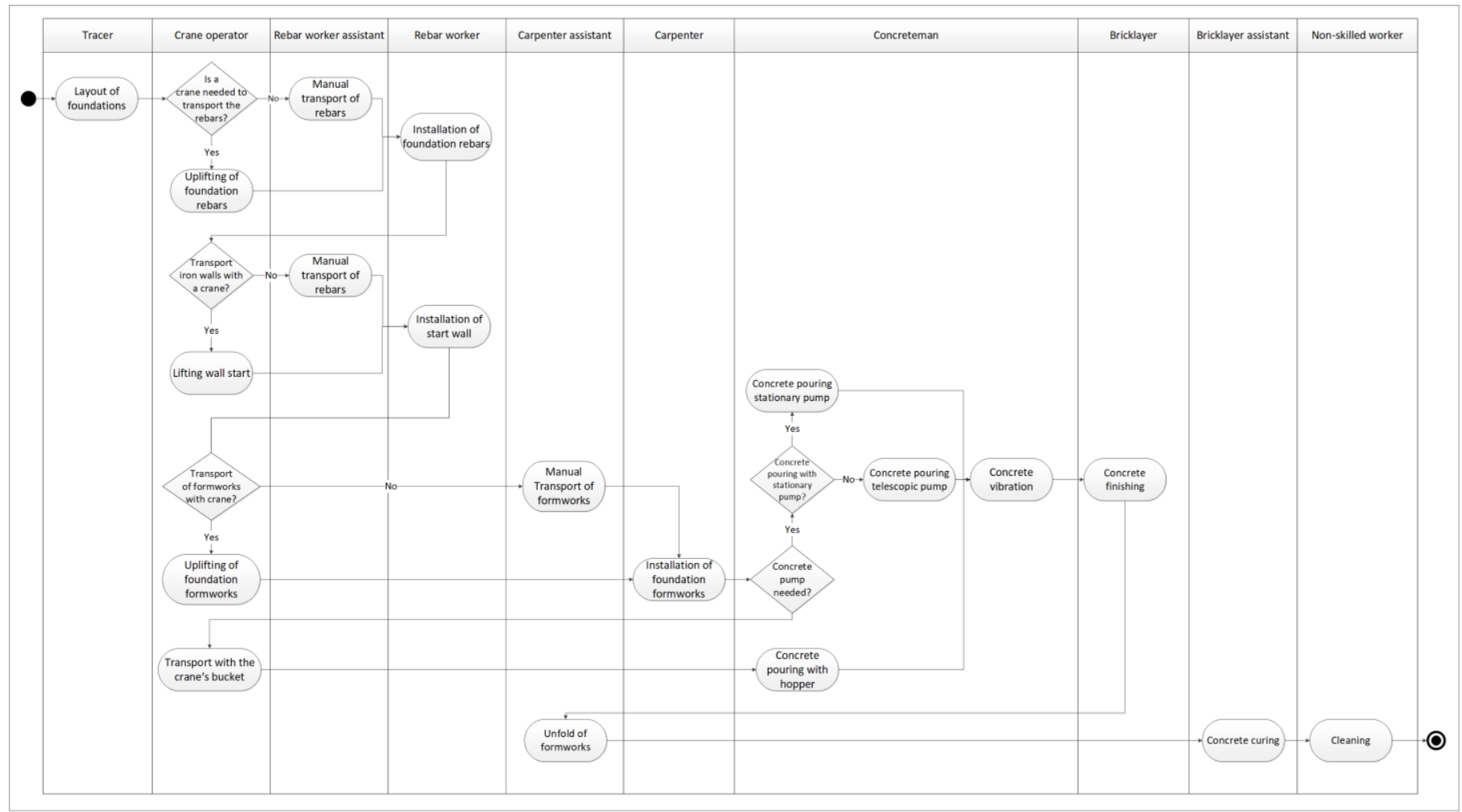

\section{F. Concrete slab foundation}

Before concreting the slab, the excavation is filled with a stabilized material, which is then compacted. Next, a layer of sand is laid, compacted, and covered with polyethylene. Reinforced steel is set, concrete is poured, and finished with a trowel. Finally, concrete is cured. Model is shown in Figure 8.

Involved resources: Mixer truck, wheelbarrows, shovels, vibrators or drive units, trowel, and steamroller.

FIGURE 8

CONSTRUCTION PROCESS OF THE CONCRETE SLAB

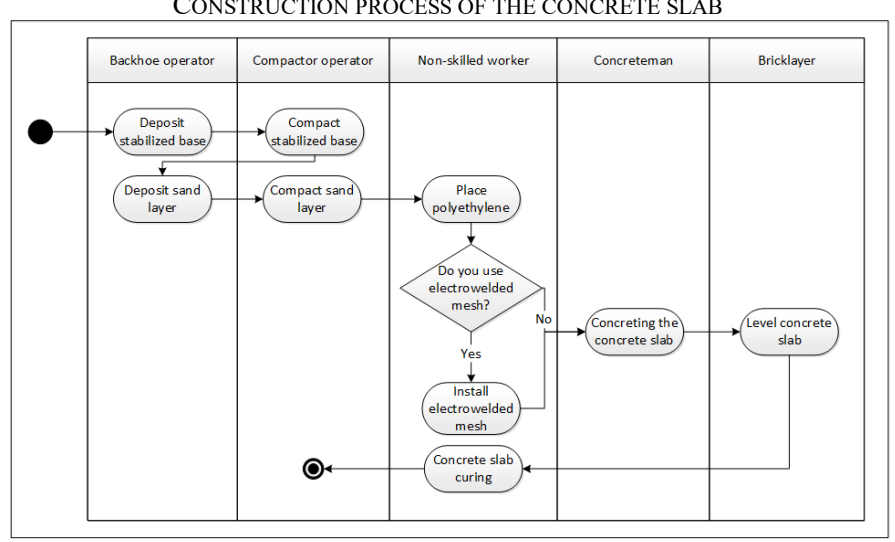

G. Walls

The construction process for walls is similar to the foundation process. The process begins with the outline of the auxiliary axes of the walls. Then the wall reinforcement is moved by crane (wall rebars are moved manually whether they are located in the first floor). Subsequently, the facilities installations (electricity, water, gas, and others if any) are placed into the walls. The formworks are then installed and the concrete is poured and vibrated. To finish the process, the formworks are removed, the concrete is cured and the site is cleaned up. In summary, the complete developed model for this process is shown in Figure 9.

Involved resources: Crane, wheelbarrows, stationary pumps, hod, concrete vibrator, concrete power trowel, and formworks.

$17^{\text {th }}$ LACCEI International Multi-Conference for Engineering, Education, and Technology: "Industry, Innovation, And 
FIGURE 9

MODEL OF THE CONSTRUCTION OF WALLS

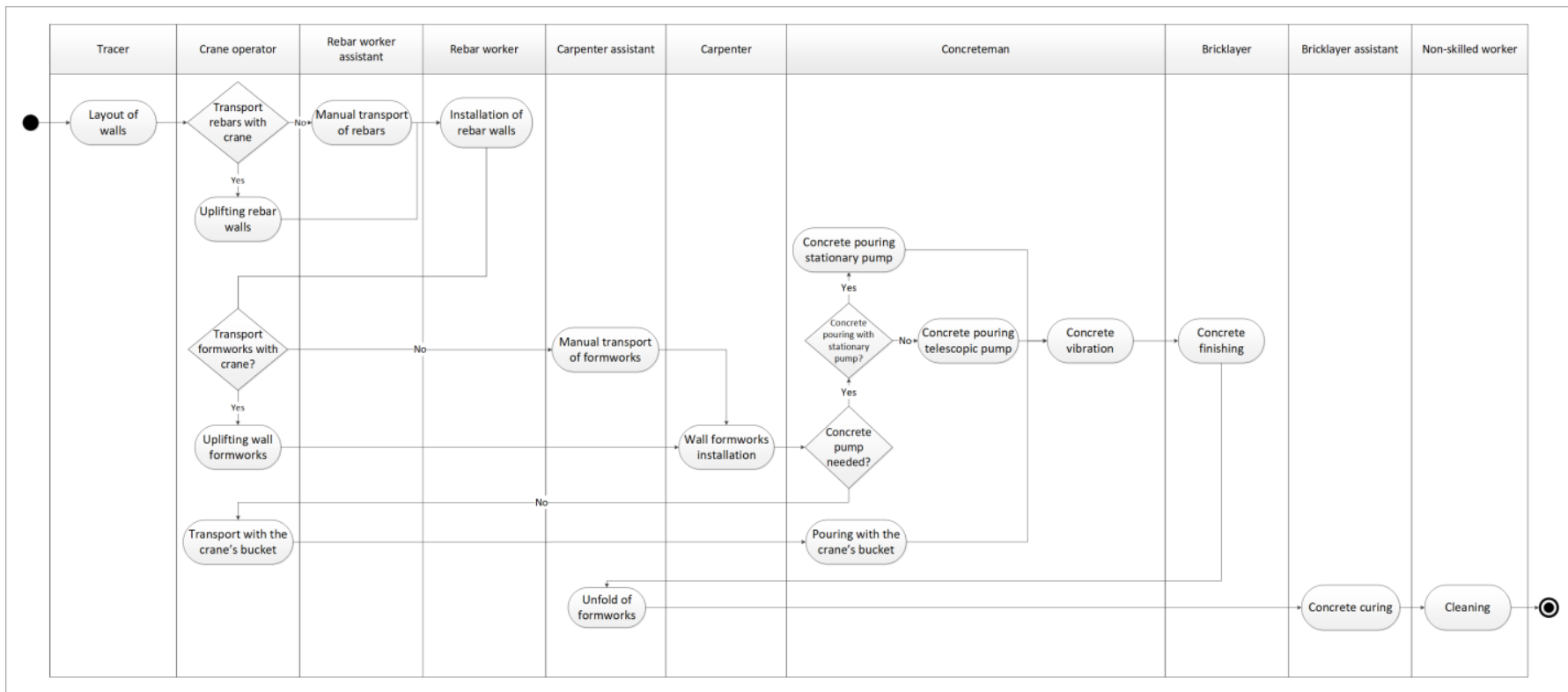

\section{H. Slabs}

To begin the construction of slabs, the story height is traced, then prongs, primary and secondary beams which hold the slab bottom are placed. The slab formworks are hoisted with the crane to be installed by the carpenters. Then, the workers trace the auxiliary lines of the wall for the placement of the formwork. The slab reinforcement is moving with crane, and then installed by the rebar workers. The reinforcement of the wall of the upper floor to the slab are also installed. Then the concretemen pour and vibrate the concrete on the slab, continuing with smoothing the concrete a trowel. Finally, the formworks are removed, the concrete is cured and the process is finished with cleaning up as shown in Figure 10.

Involved resources: Telescopic props, formworks, crane, hod, vibrator, concrete pumps, mixer truck, and trowel.

FIGURE 10

MODEL OF THE CONSTRUCTION PROCESS OF SLABS

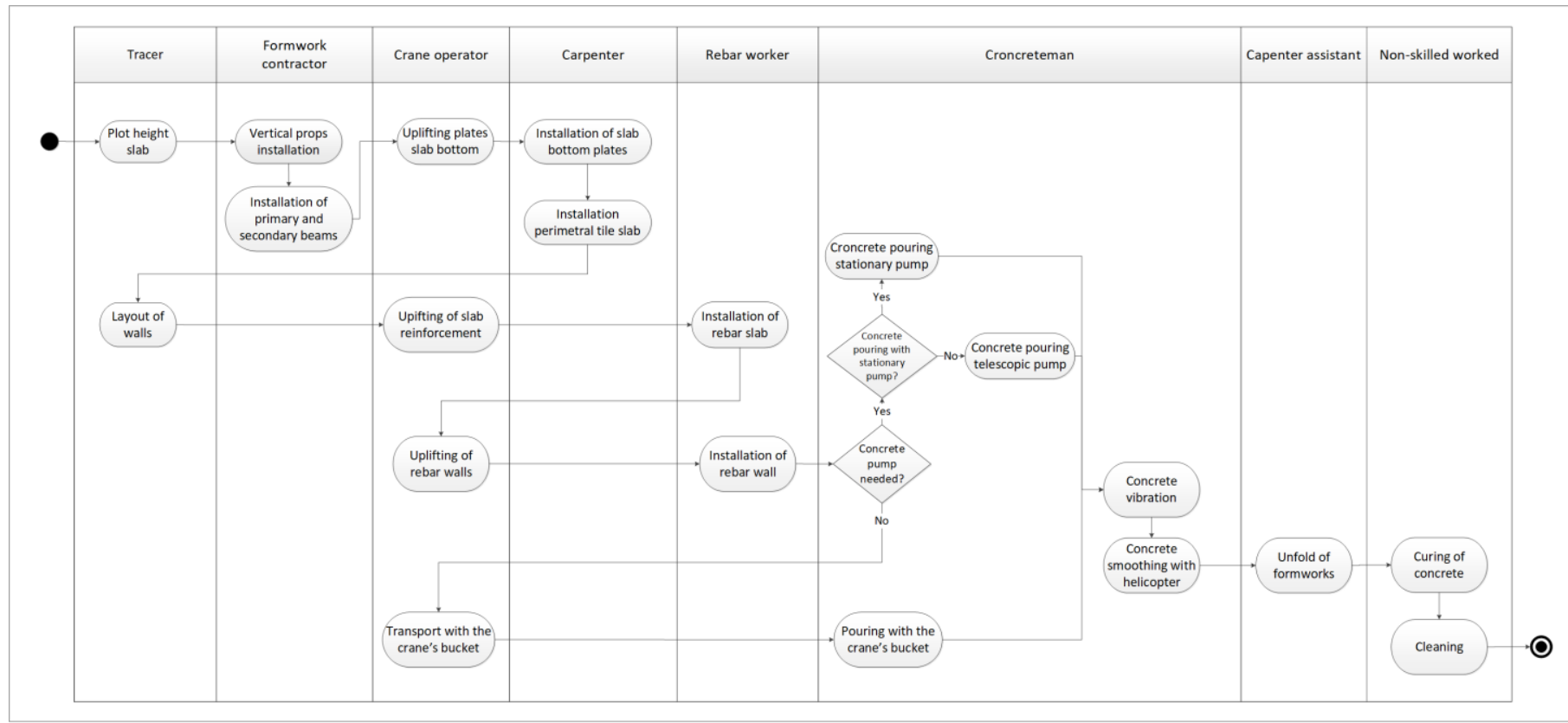

$17^{\text {th }}$ LACCEI International Multi-Conference for Engineering, Education, and Technology: "Industry, Innovation, And Infrastructure for Sustainable Cities and Communities", 24-26 July 2019, Jamaica. 


\section{Stairs}

Stairs can be built in situ or get it prefabricated. As shown in Figure 11, the construction process of the stairs built in situ begins setting the bottom formworks of the staircase, continuing with its reinforcement. Consecutively, the carpenters install the lateral forms to receive the concrete. The concrete is pumped from the truck mixer and poured, which is then vibrated and smoothed manually. To finish the construction process, the formworks of the stairs are removed and the workers clean up the site. For the installation of the prefabricated stairs a crane is used, which moves the staircase and places it in the final location, assisted by concrete workers.

Involved resources: Mixer truck, hod vibrator or drive unit trowel, prefabricated staircase, staircase bottom formworks, and stair riser.

\section{J. Upper floor and Roofings}

As the last part of the structural work stage, the upper floor has to be built as shown in Figure 12, which is similar to the construction process of slabs of previous floors.

Thus, after the construction of the upper floor, the roof is installed following the processes shown in Figure 13.

Next, the installation of the humidity barrier located above the last constructed slab is carried out. In parallel, the carpenters build and installed the trusses. Then they install the roof purlines that will hold the boards or plywood. The carpenters install the plywood plates and finally the roof is mounted.

Involved resources: formworks, crane, concrete pumps, hod, vibrator, trowel, humid barrier, and plywood.

FIGURE 11

MODEL OF THE CONSTRUCTION PROCESS OF THE STAIRS

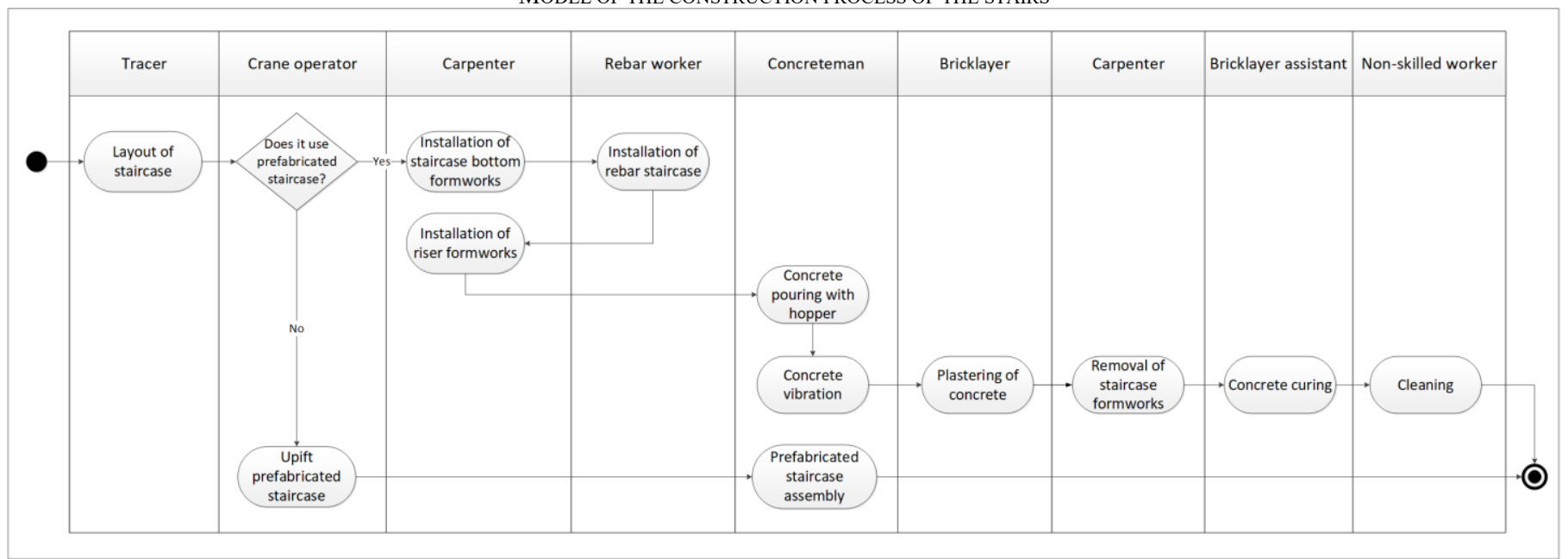

FIGURE 12

MODEL OF THE ROOF CONSTRUCTION PROCESS

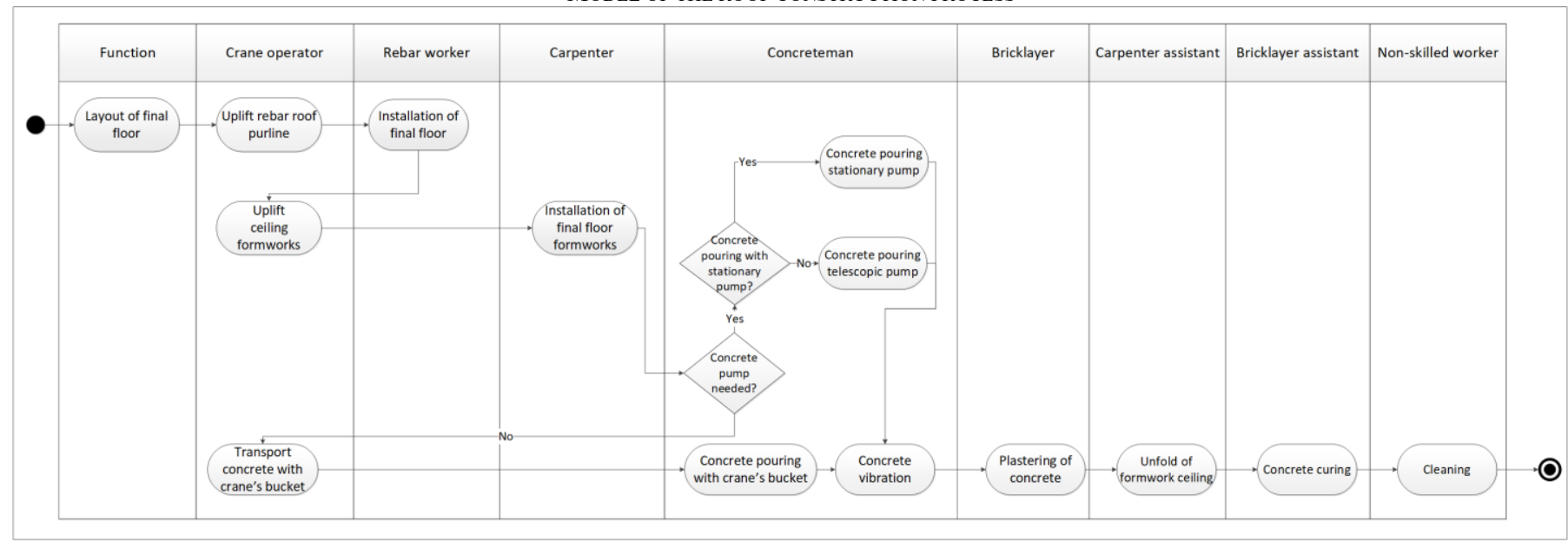

$17^{\text {th }}$ LACCEI International Multi-Conference for Engineering, Education, and Technology: "Industry, Innovation, And Infrastructure for Sustainable Cities and Communities", 24-26 July 2019, Jamaica. 
FIGURE 13

CONCEPTUAL MODEL OF ROOFING CONSTRUCTION PROCESS

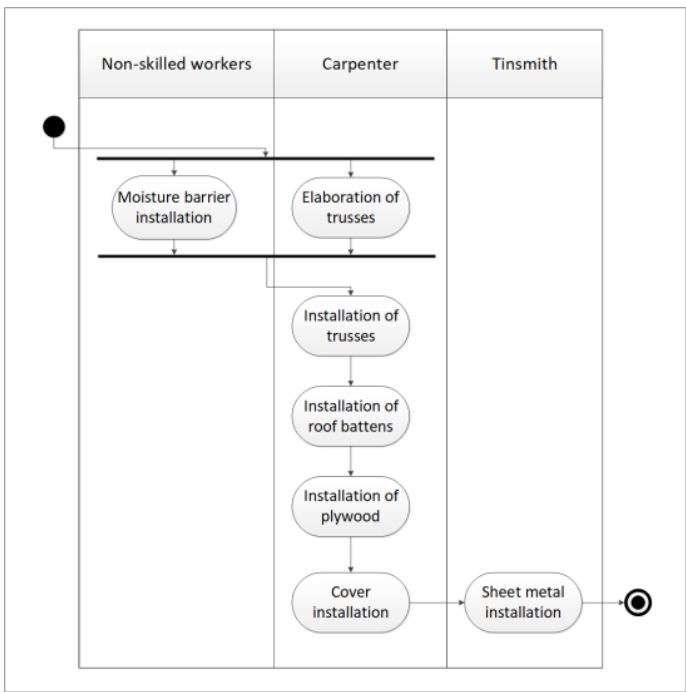

\section{K. Finishing works}

Figure 14 shows the finishing processes. First, the walls are repaired and painted. Then, diverse tasks are carried out in parallel: stairs finishings, installation of partition walls and façade's works. After the building of partition walls, the facing of ceilings, bathroom and kitchen pavements, kitchen furniture, and doors are carried out. The installation of sanitary accessories (showers, tubs, sinks, etc.) and furniture is only carried out at the end of the paving activities of bathrooms and kitchen. Finally, pavements and floors inside the building (carpets, tiles, etc.) are carried out.

FIGURE 14

MODEL OF FINISHING WORKS

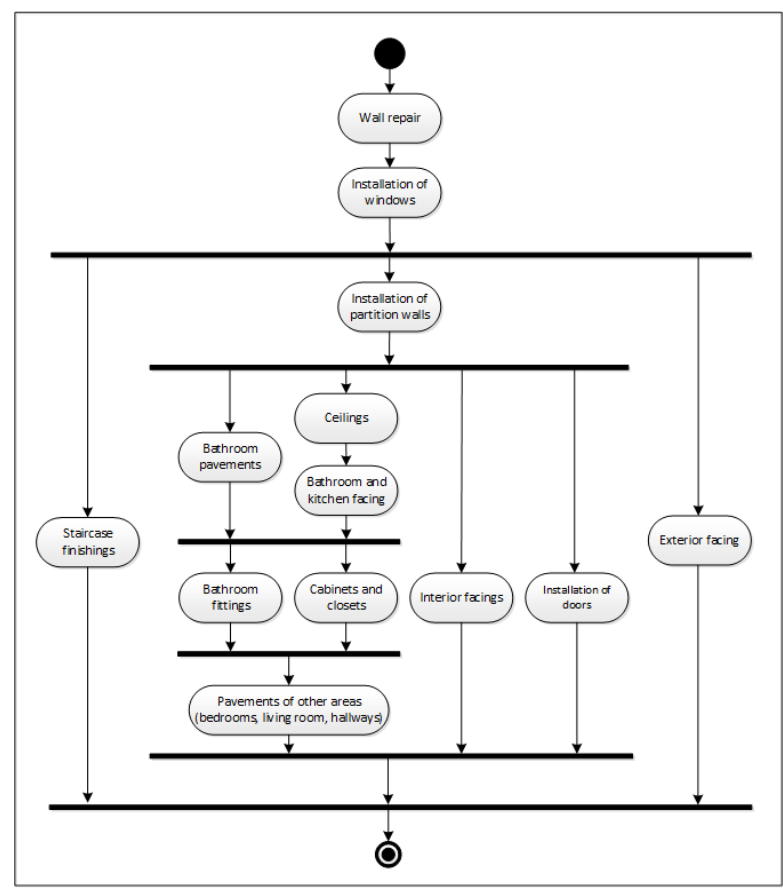

L. Final or annexed works

Final works begin with the construction of the final fences of the building. Then, trash deposits and guardhouse are built. Afterwards, the parking lots, sidewalks and concrete planters are built as shown in Figure 15.

FIGURE 15

CONCEPTUAL MODEL OF FINAL WORKS

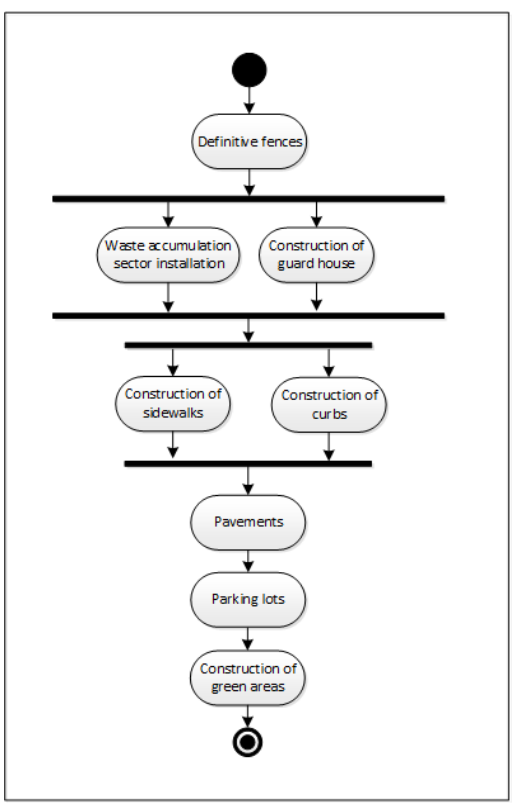

\section{GRAPHIC REPRESENTATION OF THE MODELS}

Finally, Figure 16 shows some examples of construction processes built with Flexsim ${ }^{\mathrm{TM}}$ software, based on the conceptual models presented in this paper.

FIGURE 16

CONSTRUCTION PROCESSES BUILT WITH FLEXSIM ${ }^{\text {TM }}$ SOFTWARE

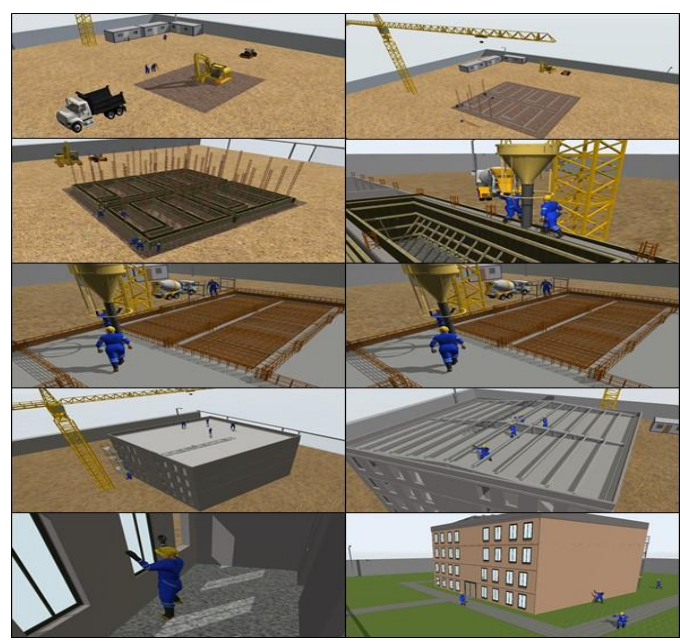

VII. GENERAL MODEL PROPOSED FOR BUILDINGS

As a summary, a general model for construction processes of building is shown in Figure 17.

$17^{\text {th }}$ LACCEI International Multi-Conference for Engineering, Education, and Technology: "Industry, Innovation, And 
FIGURE 17

COMPLETE MODEL OF THE CONSTRUCTION PROCESS OF RESIDENTIAL BUILDINGS

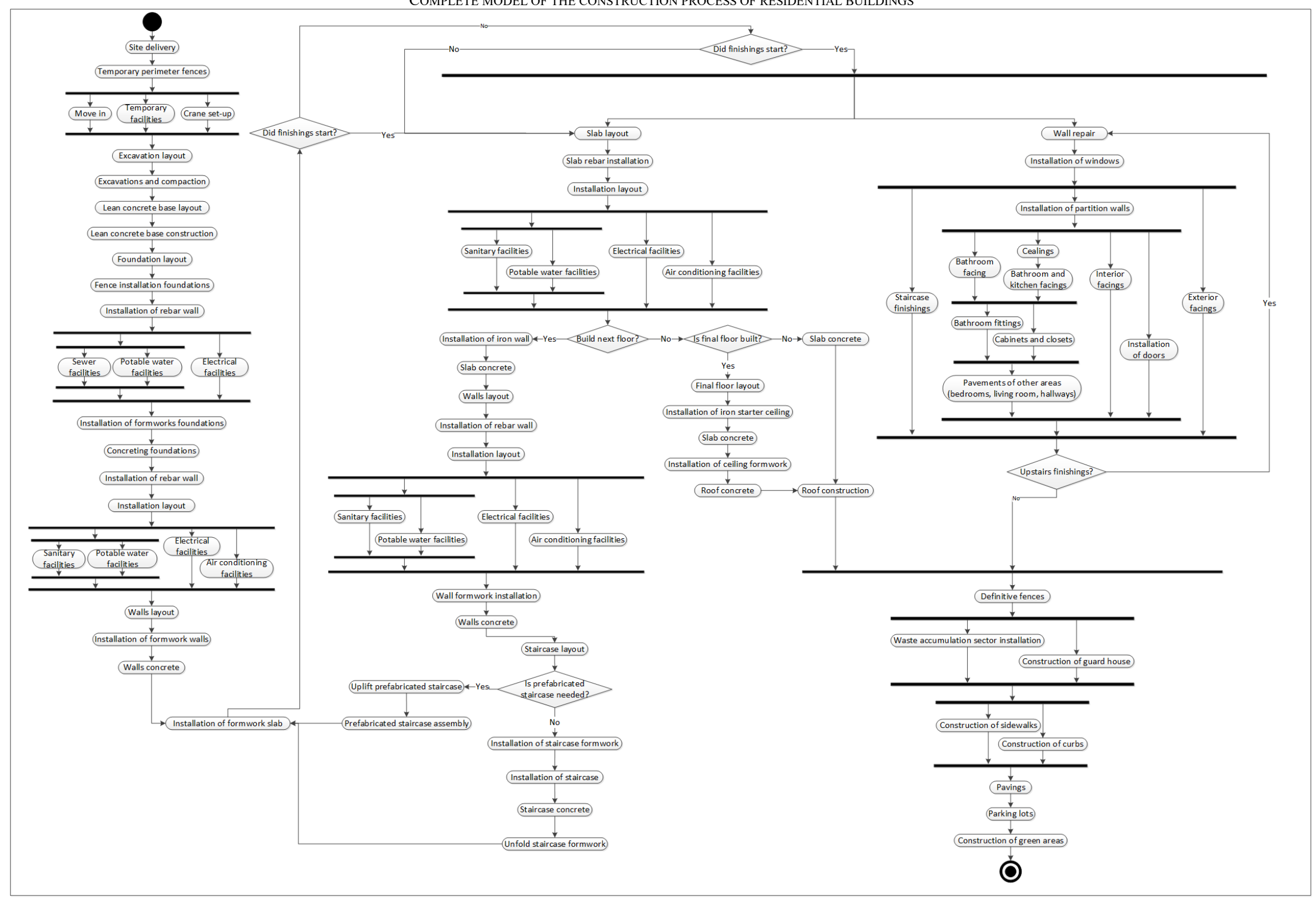

$1^{\text {th }}$ LACCEI International Multi-Conference for Engineering, Education, and Technology: "Industry, Innovation, And Infrastructure for Sustainable Cities and Communities", 24-26 July 2019, Jamaica. 


\section{CONCLUSIONS}

Ontological models allow describing various construction processes of buildings, based on simulation techniques that help construction professionals to understand them easily.

On the other hand, most of the construction methods are carried out based on experience, but with limited attention paid to bottlenecks, production rates, process times, and performance measures; key ambits of simulation, which provides a friendly visualization of construction processes.

Thus, the development of simulation ontological models to easily represent construction processes may be beneficial for all those stakeholders involved in the construction industry.

Despite the complexity and variability of the activities in construction projects, the present research was able to propose generalized models, which could be the basis for the elaboration of a library of objects for building constructive processes, adaptable to any simulation software.

\section{REFERENCES}

[1] Corfo, 2014, Programa Estratégico de Productividad y Construcción Sustentable. Available on http://www.agendaproductividad.cl/wpcontent/uploads/2014/10/PPT_Programa_Estrategico_Construccion_Sust entable-2.pdf Accessed in January 2019.

[2] Kamat, V. R., \& Martinez, J. C. (2001). Visualizing Simulated Construction Operation in 3D. Journal of Computing in Civil Engineering, 329-337.

[3] Al-Hussein, M., Athar Niaz, M., Yu, H., \& Kim, H. (2006). Integrating 3D visualization and simulation for tower crane operations on. Automation in Construction, 554-562.

[4] Labban, R., AbouRizk, S., Haddad, Z., \& Elsersy, A. (2013, December). A discrete event simulation model of asphalt paving operations. In Simulation Conference (WSC), 2013 Winter (pp. 3215-3224). IEEE.

[5] Loonen, R., Singaravel, M., Trcka, M., Cóstola, D., \& Hensen, J. (2014). Simulation-based support for product development of innovative building envelope components. Automation in Construction Volume 45, 86-95.

[6] Burks, A. W., \& Burks, A. R. (1981). First general-purpose electronic computer. Annals of the History of Computing, 3(4), 310-389.

[7] Booch, G. (2006). Object oriented analysis \& design with application. Pearson Education India.

[8] Goldsman, D., Nance, R., \& Wilson, J. (2009). A brief history of simulation. Winter Simulation Conference, 310-313.

[9] Banks, J., Carson II, J., Nelson, B., \& Nicol, D. (2013). Discrete-Event System Simulation (4th ed.). New Jersey: Pearson Prentice Hall.

[10] Chen, E. J., \& Kelton, W. D. (2008). Estimating steady-state distributions via simulation-generated histograms. Computers \& Operations Research, 35(4), 1003-1016.

[11] de Souza Vargas, T. (2007). A história de UML e seus diagramas. Departamento de Informática e Estatística, Universidade Federal de Santa Catarina (UFSC) - Florianópolis, SC - Brazil.

[12] Law, A. M. (2015). Simulation Modeling and Analysis (5th ed.). New York: McGraw-Hill Education.

[13] Pedgen, L., Miles, T., \& Diaz, G. (1985). Graphical interpretation of output illustrated by a SIMAN manufacturing system simulation. Winter simulation conference, 244-251.

[14] Halpin, D. W. (1973). An investigation of the use of simulation network for modeling construction operations. PhD Dissertation, Univ. of Illinois.

[15] AbouRizk, S. (2010). Role of Simulation in Construction Engineering and Management. Journal of constrution Engineering and Management., 1140-1153.

[16] Ioannou, P., \& Martinez, J. (1996). Comparison of Construction alternatives using matched simulation experiments. Journal of Construction Engineering and Management. Vol. 122, Issue 3., 231-241
[17] Al-Battaineh, H., AbouRizk, S., Tan, J., \& Fernando, S. (2006). Productivity Simulation During the Planning Phase of the Glencoe Tunnel in Calgary, Canada: A Case Study. Winter Simulation Conference, Monterey, CA.

[18] Kannan, G., \& Martinez, J. (1997). A framework for incorporating dynamic strategies in earth-moving simulations. 29th conference on Winter simulation, 1119-1126.

[19] Peña-Mora, F., Han, S., Lee, S., \& Park, M. (2008). StrategicOperational Construction Management: Hybrid System. J. Constr. Eng. Manage, 134(9), 701-710.

[20] Sacks, R., Esquenazi, A., \& Goldin, M. (2007). LEAPCON: Simulation of lean construction of high-rise apartment buildings. Journal of Construction Engineering and Management, 133(7), 529-539.

[21] Lu, M. (2003). Simplified discrete-event simulation approach for construction simulation. J. Constr. Eng. Manage., 129(5), 537-546.

[22] González, V., \& Echaveguren, T. (2012). Exploring the environmental modeling of road construction operations using discrete-event simulation. Automation in Construction, 24, 100-110.

[23] Verbal, R., \& Serpell, A. (1992). Modelación y simulación de operaciones de construcción. Revista Ingeniería de Construcción, $\mathrm{N}^{\circ} 1$.

[24] Baeza, J., Arcudia, C., \& González, J. (2004). Simulación estocástica de rendimientos de mano de obra en procesos de construcción. Revista Académica de la Facultad de Ingeniería Universidad Autónoma de Yucatán. Volumen 8. Número 2, 103-115.

[25] Sosa, J., Baeza, J., \& Arcudia, C. (2007). Modelo para Simulación Computarizada del Proceso Constructivo de la losa prefabricada L-18. Ing. Univ. Bogotá (Colombia), 11 (1), 71-87.

[26] Gómez, A. (2010). Simulación de procesos constructivos. Revisya Ingeniería de Construcción Vol.25 №1, 121-141.

[27] Forcael, E., González, M., Soto, J., Ramis, F., and Rodríguez, C. (2018). "Simplified Scheduling of a Building Construction Process using Discrete Event Simulation". In Proceedings of the 16th Latin American and Caribbean Consortium of Engineering Institutions LACCEI, Lima, Perú, 1-10.

[28] Pitake, S. A., \& Patil, P. D. S. (2013). Visualization of Construction Progress by 4D Modeling Application. International Journal of Engineering Trends and Technology (IJETT), 4(7), 3000-3005.

[29] Wang, W. C., Weng, S. W., Wang, S. H., \& Chen, C. Y. (2014). Integrating building information models with construction process simulations for project scheduling support. Autom. in Construction, 37, 68-80.

[30] Lu, W., \& Olofsson, T. (2014). Building information modeling and discrete event simulation: Towards an integrated framework. Automation in Construction, 44, 73-83.

[31] ElNimr, A., Fagiar, M., \& Mohamed, Y. (2016). Two-way integration of 3D visualization and discrete event simulation for modeling mobile crane movement under dynamically changing site layout. Autom. in Constr., $68,235-248$.

[32] Abaglo, A. J., Bonalda, C., \& Pertusa, E. (2017). Environmental Digital Model: Integration of BIM into environmental building simulations. Energy Procedia, 122, 1063-1068.

[33] Schmuller, J. (2001). “Aprendiendo UML en 24 Horas". Prentice Hall.

[34] Bonaparte, U. J. (2012). Proyectos UML. Diagranas de ckases y aplicaciones JAVA en NetBeans 6.9.1. Tucumán: Editorial de la Universidad Tecnológica Nacional.

[35] Grau, X., \& Sánchez, M. I. (2001). Desarrollo Orientado a Objetos con UML. Madrid: Facultad de Informática UPM.

[36] Guzmán, E. (1990). Curso elemental de edificación. Santiago: Facultad de Arquitectura y Urbanismo.

[37] de Solminihac, H., \& Thenoux, G. (2014). Procesoos y técnicas de construcción. Santiago: Ediciones Universidad Católica de Chile.

[38] Gruber, T. R. (1993). A translation approach to portable ontology specifications. Knowledge acquisition, 5(2), 199-220.

[39] Gangolells, M., \& Casals, M. (2012). Un enfoque basado en ontología para la gestión integrada del medio ambiente y de la seguridad y la salud en obra. Revista ingeniería de construcción, 27(3), 103-127.

$17^{\text {th }}$ LACCEI International Multi-Conference for Engineering, Education, and Technology: "Industry, Innovation, And 